\title{
Developing translational biological psychiatry: Learning from history to build the future
}

\section{Konstantin Demin 1,2,3,4, Darya Meshalkina1,2,3, Anton Lakstygal ${ }^{1,4}$, and Allan Kalueff ${ }^{1,2,3,5,6,7,8,9}$}

${ }^{1}$ Institute of Translational Biomedicine, Saint Petersburg State University, Saint Petersburg, Russian Federation

${ }^{2}$ Institute of Experimental Medicine, Almazov National Medical Research Centre, Saint Petersburg, Russian Federation

${ }^{3}$ Laboratory of Preclinical Bioscreening, Russian Research Center for Radiology and Surgical Technologies, Pesochny, Russian Federation

${ }^{4}$ Faculty of Biology, Saint Petersburg State University, Saint Petersburg, Russian Federation

${ }^{5}$ The International Zebrafish Neuroscience Research Consortium (ZNRC), Slidell, LA, USA

${ }^{6}$ Laboratory of Translational Biopsychiatry, Research Institute of Physiology and

Basic Medicine, Novosibirsk, Russian Federation

7ZENEREI Research Center, Slidell, LA, USA

${ }^{8}$ School of Pharmacy, Southwest University, Chongqing, China

?Ural Federal University, Ekaterinburg, Russian Federation

Address correspondence and requests for materials to Allan Kalueff, avkalueff@gmail.com
Citation: Demin, K., Meshalkina, D., Lakstygal, A., and Kalueff, A. 2017. Developing translational biological psychiatry: Learning from history to build the future. Bio. Comm. 62(4): 278-292. https://doi.org/10.21638/11701/ spbu03.2017.407

Author's information: Konstantin Demin Ph.D. Student, orcid.org/0000-00030258-2801: Darya Meshalkina, Ph.D. Researcher, orcid.org/0000-0003-3043-1197; Anton Lakstygal, Student, orcid.org/00000002-6482-4557; Allan Kalueff, Ph.D., Professor, Laboratory Head, orcid.org/00000002-7525-1950

Manuscript Editor: Yegor Malashichev Saint Petersburg State University, and Institute of Experimental Medicine, Saint Petersburg, Russia;

Received: March 16, 2018;

Accepted: April 14, 2018;

Copyright: (c) 2017 Demin et al. This is an open-access article distributed under the terms of the License Agreement with Saint Petersburg State University, which permits to the authors an unrestricted distribution and self-archiving free of charge.

Funding: This work was supported by the Russian Foundation for Basic Research (RFBR) Grant 16-04-00851.

Competing interests: The author has declared that no competing interests exist.

\section{Abstract}

Psychiatric disorders are among the most complex human disorders that, albeit often difficult to diagnose and treat, are widespread in modern society. Biological psychiatry studies biological functions of the central nervous system as mental disorders develop. Today's biological psychiatry is facing multiple conceptual problems that prevent our deeper understanding of disease pathogenesis and delay the invention of new treatments. Thus, providing a historical context to this rapidly developing field may help scientists better understand the existing challenges and their potential solutions. Here, we discuss the main conceptual problems and paradigms of biological psychiatry, including the lack of reproducibility and/or valid theories, through an historical overview of its role in addressing theoretical and clinical questions. We propose a wider use of the translational approach in psychiatry to expand our analyses of psychiatric disorders to other species, and as a tool to create and further develop theories and concepts in this field.

Keywords: biological psychiatry, translational medicine, history of psychiatry, modern psychiatry, conceptual issues in psychiatry.

\section{Introduction}

Psychiatric (mental) disorders are the most complex and frequently comorbid human disorders; they are becoming particularly widespread in modern society, but are difficult to properly characterize (Fears et al., 2014; Meyer-Lindenberg and Weinberger, 2006; Nestler and Hyman, 2010; Tsankova, Renthal, Kumar, and Nestler, 2007). Their polygenetic nature complicates genetic studies, which often yield not only disorder-specific genes but also multiple other candidate genes that are associated with other psychiatric disorders, thus showing significant overlaps (Cross-Disorder Group of the Psychiatric Genomics et al., 2013; Gaugler et al., 2014; Ikeda et al., 2013; Ivleva et al., 2010; Murphy et al., 2003; Schizophrenia Working Group of the Psychiatric Genomics, 2014; Uddin et al., 2014). Furthermore, the low specificity, lack of personalization and slow pace of innovation in psychiatric practice collectively lead to inadequate treatment of mental diseases (Griebel and Holmes, 2013; McMahon and Insel, 2012). 
Today, depression and other affective spectrum disorders represent the leading causes of human disability (Cryan and Mombereau, 2004; Murray and Lopez, 1997). Despite the high prevalence and harm caused by both depressive and comorbid disorders, they remain poorly understood and are often treatment-resistant and recurrent (Cryan and Mombereau, 2004; Huynh and McIntyre, 2008; Insel and Charney, 2003; Schmidt, Wang, and Meijer, 2011; Wong and Licinio, 2004).

As a field, biological psychiatry studies biological functions of the central nervous system (CNS) and development of mental disorders. In a broad sense, this vibrant field represents a set of changing ideas, approaches and social practices aiming to describe and cure deviant human behavior in terms of neurobiological discourse (D'haenen, den Boer, and Willner, 2002). To better understand the main conceptual problems that biological psychiatry faces today, and to find potential ways of their resolution, it is critical to first consider the historical perspective and main milestones in this field (Fig. 1).

\section{Milestones in biopsychiatric concepts}

The science studying psychiatric disorders - psychiatry - has a much longer history than neurology, which examines disorders with relatively clear and known neural pathology (Wickens, 2014). In fact, many currently recognized psychiatric conditions (e.g., mania, melancholy, and hysteria) were known in the time of Hippocrates (Wickens, 2014), who in his Aphorisms noted that most of our feelings, if they are prolonged, should be considered symptoms of illness (Hippocrates, 2004). One of the first preserved notions of clinical depression is the 1500 BC Ebers Papyrus (Scholl, 2002). Notably, the term "melancholy" at that time was broader in meaning than it is now, and included not only low mood, despair and loss of energy, but also fear, aggression, obsessions and even hallucinations, thus incorporating depression, anxiety and psychotic disorders together (Radden, 2003).

In early works, pathology of psychiatric disorders was described as an imbalance of humors associated with relevant temperaments (Wickens, 2014) - the concept of humoralism in early psychiatry. This theory was based on 4 humors (blood, yellow bile, black bile and phlegm), the imbalance and "corruption" of which resulted in diseases and disabilities (Lindemann, 2010; Lloyd, 1983). It is possible that humoralism originated in Ancient Egypt or Mesopotamia (Sudhoff and Garrison, 1926; Van Sertima, 1992), but it was later adopted and developed by Hippocrates (Lloyd, 1983). A fourtemperament typology that linked imbalance of humors with temperaments was developed by Galen, who associated each humor with the combination of 2 different qualities (hot/cold and dry/wet), jointly determining

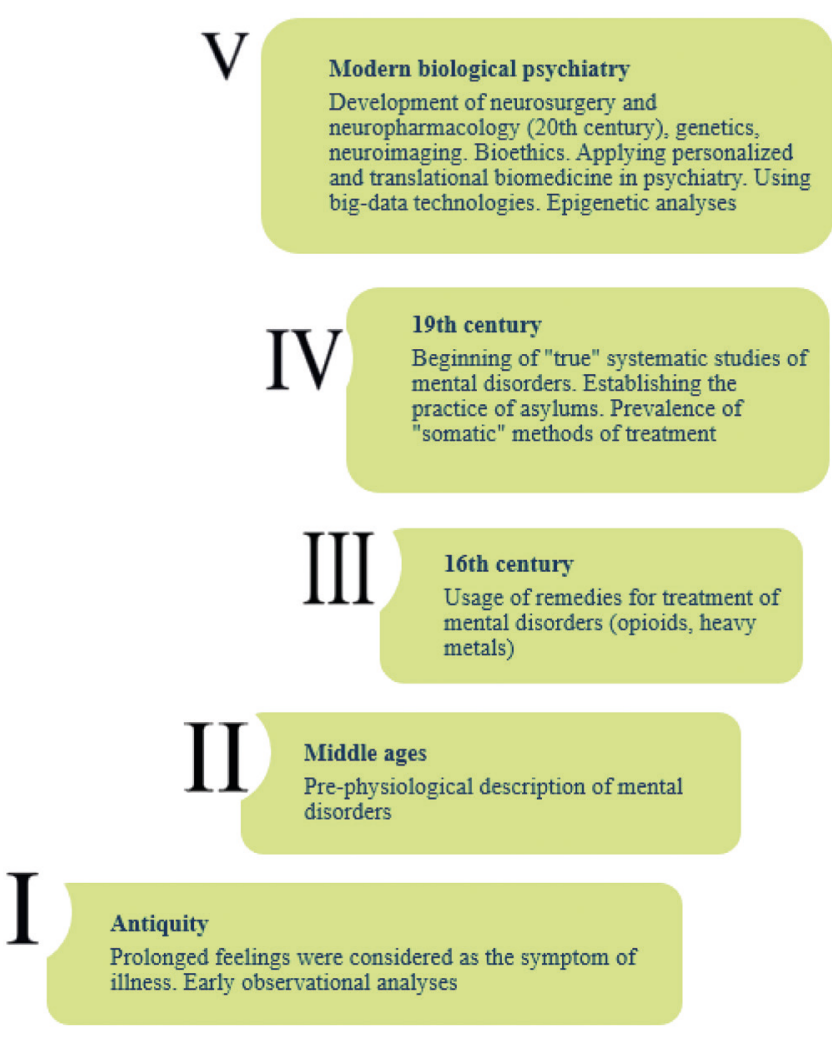

Fig. 1. A brief history of biological psychiatry. It was already mentioned by Hippocrates that most of our feelings, if they are prolonged, should be considered symptoms of illness. Further development of psychiatry was the direct consequence of the growth of medical practice, resulting in pre-physiological hypotheses of mental disorders. Finally, contemporary psychiatry uses a wide variety of treatment methods and modern diagnostic tools.

the respective temperament (sanguine, choleric, melancholic and phlegmatic) (Boeree, 2014; Kagan, Snidman, Arcus, and Reznick, 1994). This influential concept was widely accepted and used by physicians and researchers, most notably by Avicenna (Lutz, 2002), and it was displaced only with the rise and development of modern theories of CNS pathology and cellular biology.

Before the "true" scientific study of mental disorders began in the late $18^{\text {th }}$ and $19^{\text {th }}$ centuries, their "treatment" was characterized mostly by societal prejudices and punishments, as patients remained highly stigmatized, despite some concern about mental health in times of Greek prosperity and their treatment with different holistic methods (Panksepp, 2004b, 2004c). While some humanistic positions existed in Middle Eastern countries, European countries remained in the Dark Ages for a long time, during which demonization of mental disorders dominated both society and medicine (Andreasen, 2004; Murad and Gordon, 2002; Panksepp, 2004b; Stone, 1997). Indeed, many widely used biological methods of therapy for mental disorders included drubbing, bleeding, starvation and temperature shock; they were based on prejudices rather than scientific rationale, and have since been recognized as ineffective 


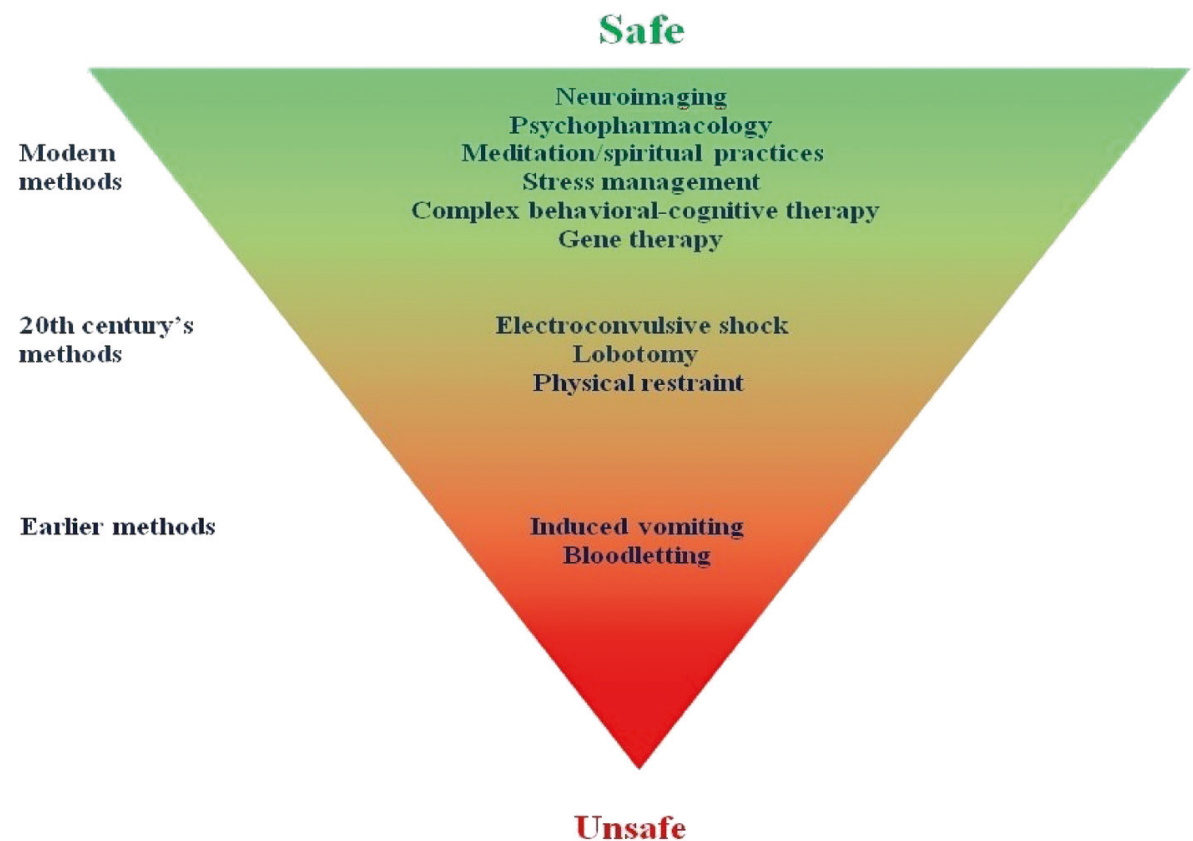

Fig. 2. Evolution of selected commonly used psychiatric treatment methods. The size of each phase displays treatment capacity of methods used at particular time. The color reflects the relative safety of implemented treatments, from safe (green) to unsafe (red).

in modern practice (Panksepp, 2004b) (Fig. 2). Among the relatively effective methods used were placebo-and psychotherapy-like methods that involved witch doctors, shamans and even skull trepanation for so-called "bad spirits extraction" (Panksepp, 2004b). Interestingly, conceptually similar approaches, based on sympathy/social concern and the placebo effect, are currently well known and are used in psychiatric practice with proven therapeutic effects (Harrington, 1999; Mayberg et al., 2002; Moerman, 2002; Panksepp, 2004a; Petrovic, Kalso, Petersson, and Ingvar, 2002; Shapiro and Shapiro, 2000).

Certain views about somatic causes of mental disorders, which are now fundamental in biological psychiatry, could already be found in the $17^{\text {th }}$ century. For example, Thomas Hobbes (1588-1679) suggested that motions of blood, animal spirits, "body parts" and organs caused by phantasms concerning good and evil in the mind may lead to "madness" (Gert, 1996; Hobbes, 1972; Hobbes and Macpherson, 1968). "Madness" was defined as excessive passions, the motion of which "may cause disturbances in different body parts" (Gert, 1996; Hobbes and Macpherson, 1968). Famous iatrochemist and early brain researcher Thomas Willis (1621-1675) also emphasized somatic causes of diseases and noted that brain function disturbances may lead to psychiatric disorders, such as melancholia (Frank, 1980; Willis and Guidott, 1992). Willis also believed such changes to be potentially revealed by anatomical pathology methods like autopsy (Conry, 1978). Around the same time, Robert Burton (1577-1640) published The Anatomy of
Melancholy, describing melancholic condition in detail, overviewing theories of its causes, expressing his own feelings and suggesting a healthy diet, proper sleep, music, work and social communication as effective treatment methods (Burton, 1931).

Nevertheless, the role of the nervous system in the function of a healthy individual as well as in the progress of pathological conditions was not actively studied until the $18^{\text {th }}$ century (Wickens, 2014). Around that time, CNS disorders became especially recognized by the rapidly growing medical practice (Wickens, 2014). The existence of clear organic bases for neurological diseases provided neurological methods that were not accessible for psychiatry, and in this way neurological studies built the foundation for further development of psychiatry (Panksepp, 2004b; Wickens, 2014). For example, case history review or autopsy were used by Giovanni-Battista Morgagni (1682-1771) and further applied in neurology by Jean-Martin Charcot (18251893), facilitating the relatively fast growth of neurology in the $18-19^{\text {th }}$ centuries (Wickens, 2014). Interestingly, as a result of his postmortem studies of psychiatric patients, Morgagni emphasized the lack of reproducibility of others researchers' results (Bonet, 1700; Morgagni, 1769), also noting that the same diseases may show lesions in different parts of the brain (Morgagni, 1769). However, further development of ideas about the role of the brain in human life continued. For example, Pierre Cabanis (1757-1808) suggested that the brain "excretes" thoughts and this may create complex conscious and mental disorders (Cabanis and Cerise, 1843). 
In the meanwhile, studying psychiatric disorders required other approaches, given the lack of pronounced organic lesions and the wide diversity that complicates classification (Wickens, 2014). The $19^{\text {th }}$ century (especially the 1850-1900s) is often called the beginning of true thorough and systematic studies of mental disorders (Panksepp, 2004b). This period started with the works of Benjamin Rush (1745-1813) in the USA, Philippe Pinel (1745-1826) in France and Vincenzo Chiarugi (17591820) in Italy, who laid the foundation of "moral treatment" of patients (Panksepp, 2004b). Specifically, they helped establish the practice of asylums for psychiatric patients in small humanistic hospitals, in which therapeutic space was created to recover patients' emotional homeostasis (Panksepp, 2004b). Besides "psychological" treatment, some auxiliary "somatic" methods, such as bloodletting, induced vomiting, diets, physical restraint and electroconvulsive shock, were used, but collectively fell into decline by the $20^{\text {th }}$ century (Panksepp, 2004b).

Etienne-Jean Georget (1795-1828), based on Marie F.X. Bichat's (1771-1802) ideas of vitalism, suggested that mental disorders have an organic nature and introduced the term "technology alibi", which plays a critical role in today's biopsychiatry (Berrios and Marková, 2002; Georget, 1820). The technology alibi is a fundamental assumption of psychiatry that is based on syllogism: the mind is represented in the brain - the mind is tantamount to a set of behaviors - hence, all behaviors are represented in the brain - abnormal behaviors are still behaviors - hence, all behaviors have brain representation - thus, the fact that no brain representation can yet be found for mental disorders must be due to faulty techniques (Berrios and Marková, 2002). In this way, the technology alibi plays a large role in biological psychiatry, providing it freedom to investigate psychiatric diseases as brain diseases without rigorous proof of this claim.

Similarly, Wilhelm Griesinger (1817-1868) viewed all mental diseases as brain diseases, and considered brain lesions as a physiological, not anatomical concept (Berrios and Marková, 2002). However, although Griesinger called mental disorders organic or biological in nature, he did not presume that these disorders must have a reflection in the brain, so his views on physiological lesions were closer to psychological trauma (Porter, 1988). He also noted that official clinical categories would always be arbitrary, whereas "elementary" analytical units (symptoms) are ontologically stable (Berrios, 1996). Theodor Hermann Meynert (1833-1892) described pathological conditions as changes in brain blood supply, and the main causal mechanism - as changes in cellular nutrition caused by these blood supply disruptions and birth defects (Berrios and Marková, 2002; Meynert, 1885). Interestingly, Carl Lange's (1834-1900) theory of emotion was proposed in almost the same period, and is also linked blood circulation, vasoconstriction, perfusion and nutrition to pathological affective conditions (Wassmann, 2010).

A seminal step in the study of psychiatric disorders was made by Emil Kraepelin (1856-1926), often called the father of modern psychiatry (Panksepp, 2004b; Wickens, 2014). Kraepelin first described "dementia praecox", which is now widely known as schizophrenia, and created a dichotomic classification of psychiatric disorders into neuroses and psychoses, which has influenced many others classifications and theories that now are widely used by health organizations (Wickens, 2014). Notably, Kraepelin's classification was largely influenced by Karl Ludwig Kahlbaum (1828-1899) and his protégé Ewald Hecker (1843-1909) (Berrios, 1996; Berrios and Hauser, 1988; Kendler and Engstrom, 2016; Kraepelin, 1905; Kraepelin, 1983), who paid special attention to criticizing the imperfection of $19^{\text {th }}$-century psychiatric systematics (Kendler and Engstrom, 2016). For example, they noted that this systematics consisted of the symptom complexes, but not the diseases, and recognized that their high heterogeneity complicates understanding of the etiology, the prognosis of course of the diseases and their treatment (Kahlbaum, 1863; Kahlbaum and Berrios, 1996; Kendler and Engstrom, 2016; Kraam, 2004). In response, they suggested a new method of detailed and empirical observations, in which special attention should be paid to broad temporal spectra of disease progression in patients (Kendler and Engstrom, 2016). They identified and described such conditions as hebephrenia, catatonia and cyclic madness (Baethge, Salvatore, and Baldessarini, 2003; Hecker and Kraam, 2009; Kahlbaum, 1973; Kendler and Engstrom, 2016), which were further conceptually developed by Kraepelin (Kendler and Engstrom, 2016).

Kraepelin's main work, Textbook of Psychiatry, played a major role in the development of biological psychiatry (Wickens, 2014). In Kraepelin's time, psychiatric disorders were typically diagnosed by the main, most pronounced symptom (e.g., melancholia or madness) which was typically caused by a trauma, such as loss of a friend (Wickens, 2014). Subsequently, Kraepelin made several important observations. For example, comparing the speed of disease progression, he concluded that all diseases can be split into "curable" or "incurable" based on their progression speed (Wickens, 2014). Studying patients with different early clinical representations that later progressed into senile dementia, he found that these conditions can be described as united, called it dementia praecox, and distinguished it in it such subtypes as regular, paranoid, catatonic and hebephrenic (Wickens, 2014). Furthermore, Kraepelin was the first to split psychosis (then viewed as a disjointed cluster of diseases with unclear organic causes) into manic depression and dementia praecox (Wickens, 2014). At the same time, 
manic depression itself consisted of all affective spectrum pathologies and was split into externally and internally caused disorders (Davison, 2006). Interestingly, Kraepelin thought that dementia praecox was an incurable disease, in contrast to depression, which is relatively curable and temporal (Wickens, 2014). In contrast, Eugen Bleuler (1857-1939) suggested that dementia praecox could not be an incurable condition since he could see significant improvement in many patients, and argued that this condition is determined through disorganized thinking caused by the split of emotional and intellectual functions (Wickens, 2014). The term "schizophrenia" was chosen for this condition, and its main symptoms were recognized as reduced emotional response, weakened associations, indifference or inability to make choices, and autism (at that time the term was used to describe concentration on a person's own thoughts) (Wickens, 2014). Also, Bleuler noticed that symptoms of schizophrenia can be grouped into positive (e.g., excess activity and thinking) and negative (e.g., reduced or impaired/insufficient activity and thinking) (Wickens, 2014).

Another important opponent of Kraepelin was Carl Wernicke (1848-1905), deservingly considered one of the most important psychiatrists of the $19^{\text {th }}$ century (Lanczik, 1988). One of Wernicke's key findings was the creation of the first CNS model that reflected the connection between different areas of the brain and specific behaviors. This thought was the first of its kind, and highly suitable for direct pathophysiological studies; it was the first example of a model that used a neuropsychological approach for psychiatric disorders (Berrios and Marková, 2002). Interestingly, his model was based on Meynert's ideas that the brain is filled by projections and associative fibers, in which conscious is based (Berrios and Marková, 2002; Wernicke, 1906). Thus, projection lesions lead to neurological diseases, and lesions of the associative system - to psychiatric disorders (Berrios and Marková, 2002; Stein and Ludik, 1998).

In Kraepelin's time, there already were established psychopharmacological practices (Preston, O’Neal, and Talaga, 2010). For example, Kraepelin himself often used opium, morphine, scopolamine and hashish for stimulation, whereas to induce sleep he used chloral hydrate, ether, alcohol, chloroform and bromides (Spiegel, 2003). However, Kraepelin noticed that none of these drugs could treat psychiatric disorders, their use was rather short-term, and some of them could cause addiction (Preston et al., 2010). As other authors reported, the use of these drugs can help to gain control over a patient by sedation, but cannot treat psychotic symptoms per se (Preston et al., 2010).

Important, but rather underappreciated, is the contribution to biological psychiatry made by Constantin von Monakow (1853-1930) and Raoul Mourgue (18861950) (Berrios and Marková, 2002; von Monakow and
Mourgue, 1928), who pointed out that neuropsychiatric phenomena and functions should be viewed as inseparable from the function of time, making an analogy to a process of movement (Berrios and Marková, 2002). According to these views, it may not be correct to associate these processes with specific brain areas in isolation from a change in location of such processes with time (Berrios and Marková, 2002). Indeed, the brain processes information in different areas in complicated patterns, and these diverse parts need to constantly coordinate their functions. Expanding this idea, a psychiatric disorder can be seen as a consequence of time-function disturbance, and should be viewed with the use of the time concept (Berrios and Marková, 2002). Thus, Monakov and Mourge's theory of chronogenic localization was one of the first dynamic models in biological psychiatry.

Adolf Mayer (1866-1950) actively promoted a holistic ("whole self") approach to psychiatric treatment in the late $19^{\text {th }}-$ early $20^{\text {th }}$ centuries (Panksepp, 2004b). For example, he actively used thorough documentation of patients' lives; he also rightly emphasized the importance of both psychological and biological effects that may impact the patient for effective treatment, and the uniqueness of each individual's traits and, consequently, their treatment (Panksepp, 2004b). Mayer's approach was key for pioneers in the field of studying animals' self-regulation, such as Kurt Richter (1894-1988) with his study of appetite, sleep and circadian rhythms (McHugh and Slavney, 1998). Mayer's views about individuality, including his belief that a person's strong and weak sides ought to be taken into account in treatment, have further developed and can be seen today in genetic approaches and personalized medicine in treatment practice (Panksepp, 2004b). In the context of depression, Mayer noted the importance of the interaction of social and biological factors, which mediates individual reactions, and he especially emphasized his preference for the term "depression" rather than "melancholy" (Lewis, 1934).

The second half of the $19^{\text {th }}$ century raised other spectrum ideas that were closely related to psychiatry. For example, Sigmund Freud's (1856-1939) theory of psychoanalysis and psychodynamic approach revolutionized our view of the mind by the popularization of the idea of the unconscious (Panksepp, 2004b). After a slump in interest in Meyer's concept in the 1940s, psychological theories of Viktor Emil Frankl (1905-1997), Albert Ellis (1913-2007), Aaron Beck (born 1921), Freud and others, became influential and widely recognized (Beck, 1979; Blair, 2004; Carhart-Harris et al., 2014; Ellis, 1962; Frankl, 1976; Freud, 1984; Radden, 2003; Seidner, 2009). However, the lack of rigorous scientific argumentation, along with the success of pharmaceutical therapy of psychiatric disorders, led to justified criticism of Freud's theories in the late $20^{\text {th }}$ century. Nevertheless, 
these theories continue to be further developed in modern time and have gained improved scientific basis by neuropsychoanalytic methods (Panksepp, 2004b; Solms and Turnbull, 2002).

During this period, there were still multiple manipulations that are now considered radical, such as metrazole- or insulin-induced seizures, electroconvulsive therapy and lobotomy (Panksepp, 2004b; Valenstein, 1974). Widespread use of psychosurgery helped to effectively stabilize agitated psychotic patients, but it was done at a high human cost, since lobotomized patients often became unenergetic, passive and "emotionally dead" (Preston et al., 2010). Electroconvulsive treatment, on the other hand, could have a good effect on some patients (Preston et al., 2010). However, its use was far from perfect and often led to strong side effects. Furthermore, it was widespread and prescribed inappropriately, often ignoring the lack of positive response in some groups of patients (Preston et al., 2010). However, the most affected patients continued to be kept in overcrowded hospitals and "treated" with such crude methods as isolation and restraint, due to the absence of other, more effective therapies (Preston et al., 2010).

The next period in biological psychiatry, which is often called psychopharmacological, started with the discovery of highly efficient chlorpromazine by Jean Delay (1907-1987) and Pierre Deniker (1917-1998), and lithium drugs by John Cade (1912-1980) in the late 1940s - early 1950s (Cade, 2000; López-Muñoz et al., 2005; Panksepp, 2004b). These findings led to an avalanche of psychopharmacological discoveries. For example, Paul Janssen (1926-2003), based on the knowledge that chlorpromazine-like drugs cause their effects primarily through the dopaminergic system, created haloperidol and risperidone - the ancestors of today's atypical antipsychotics (Panksepp, 2004b).

Around the same time, the first drugs with antidepressant activity were discovered, as Delay and Max Lurie tested an antitubercular drug, isoniazid (which also caused a stimulating effect in patients), and found improvement in depressed patients after treatment with the drug (Ayd and Healy, 1996; Healy, 2001; Selikoff and Robitzek, 1952). The effect of iproniazid was discovered in the same way (López-Munoz, Alamo, Juckel, and Assion, 2007; Robitzek, Selikoff, Mamlok, and Tendlau, 1953). The antidepressant effect of these two drugs is related to their inhibition of monoamine oxidase A (MAO-A) (López-Munoz et al., 2007). Additionally, Roland Khun (1912-2005) presented the first tricyclic antidepressant, imipramine, following an attempt to improve chlorpromazine action (Kuhn, 1958). As a result of translational research of the 1960s, benzodiazepines anxiolytic drugs that cause sedative and antiagressive effects, such as chlordiazepoxide - were also introduced (Panksepp, 2004b). In the USSR, Svyatoslav Lapin and
Grigory Oxenkrug put forth the serotonergic theory of depression (Lapin and Oxenkrug, 1969), which subsequently led to the discovery of selective serotonin reuptake inhibitors (SSRIs) - currently, the most prescribed (Coupland et al., 2015) and one of the most efficient antidepressant medications today (Cuijpers, van Straten, van Oppen, and Andersson, 2008).

Clinical success of psychopharmacological drugs and the development of neurochemical synaptic transmission theory dramatically accelerated the description of the main neurochemical brain systems and the growth of preclinical psychopharmacology (Charney, Buxbaum, Sklar, and Nestler, 2013; D'haenen et al., 2002; Panksepp, 2004b; Preston et al., 2010). Consequently, powerful behavioral analysis and psychoactive drug screening methods were created. In such studies, animals were essentially used as "biological computers" in which drugs with potential psychoactive effect were placed, and behavioral reactions were collected as output information reflecting the effect of the drug. However, excessive focus on such methods led to a relatively slow pace of psychobehavioral systems' analyses (Panksepp, 2004b), thus necessitating further development of methodology and theories in this field.

With the advent of genetics, the focus of biological psychiatry began to shift to identifying family patterns in psychiatric disorders. As these studies shed light on a high genetic load of some psychiatric disorders, finding the genetic component of other diseases proved to be complicated (Preston et al., 2010). Recent advantages in biotechnology have made it possible to systematically test single nucleotide polymorphisms or large copy number variants by genome-wide association studies (GWAS) (Wray et al., 2014). Today, various copy number variants are found for shizophrenia, autism, bipolar and major depressive disorders (Lee and Avramopoulos, 2014). Other approaches that are relatively effective and widely used in translational psychiatry include diseasespecific differential gene expression studies. Unfortunately, both approaches consistently reveal significant overlaps and shared molecular pathways across psychiatric disorders (Cross-Disorder Group of the Psychiatric Genomics, 2013; Gandal et al., 2018). Furthermore, although some disorders show high heritability, for the vast majority of cases, their genetic etiology remains unclear, meriting further scrutiny (Lee and Avramopoulos, 2014).

While psychiatric genetics countinues to grow with improvements in experimental and analytical methods, the field of psychiatric epigenetics has also begun to gain momentum (Lee and Avramopoulos, 2014). Epigenetics refers to processes that alter gene expression without changes in DNA sequence, primarily through DNA methylation and changes in histone structure (Roach, Bronner, and Oreffo, 2011). Multiple studies have shown 


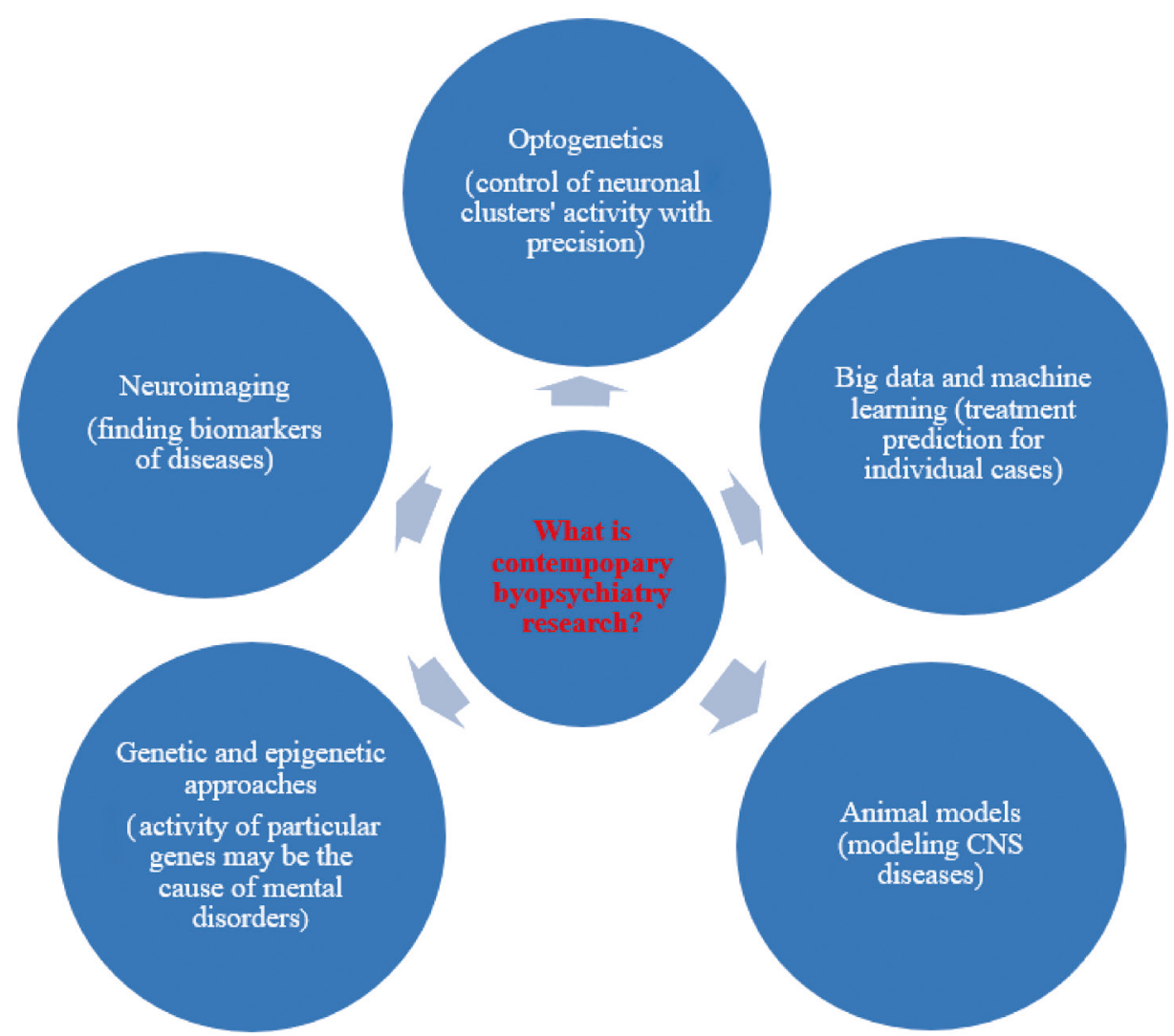

Fig. 3. The diversity of common methods used in contemporary research in biological psychiatry research, and their potential implementation.

the role of epigenetics mechanisms in different aspects of psychiatrc disorders (Peedicayil, Grayson, and Avramopoulos, 2014; Yasui, Peedicayil, and Grayson, 2016), although it remains unclear how exactly epigenetic factors contribute to the pathophysiology of specific mental disorders (Kato, 2009).

In parallel, the first international classifications of mental disorders were created, thereby continuing Kraepelin's work (APA, 1960) and putting forth novel disorder constructs and theories. For example, depression pathogenesis theories developed then primarily viewed the disorder as a neurochemical imbalance (Schildkraut, 1965), and were based on robust antidepressant effects that continue to play an important role in today's scientific discussions and antidepressant development.

Finally, modern biological psychiatry is a skyrocketing field powerfully enriched by many new effective methods and tools (Fig. 3). For instance, neuroimaging has emerged as a valuable tool that allows researchers to investigate brain structures and activity of humans and animals in vivo (Linden, 2012; Misgeld and Kerschensteiner, 2006). These techniques include computerized tomography (CT) and magnetic resonance imaging (MRI), functional magnetic resonance imaging (fMRI), positron emission tomography (PET), single photon emission computerized tomography (SPECT), near- infrared spectroscopy (NIRS), magnetoencephalography (MEG) and electroencephalography (EEG)/eventrelated potentials (ERP) (Linden and Fallgatter, 2009). Developing early neuromorphological works of Ramon y Cajal (1852-1934) (Finger, 2000) and Alois Alzheimer (1864-1915) (Berrios, 1990), modern neuroimaging studies in psychiatry picked up in 1976 with the finding of enlarged cerebral ventricles in schizophrenics (Johnstone, Crow, Frith, Husband, and Kreel, 1976). Neuroimaging can potentially be used to find biomarkers of disease, prognosis or treatment; investigate biological pathways; and help redefine diagnostic boundaries and monitor new therapies (Linden, 2012). Unfortunately, although some imaging and electrophysiological phenotypes are associated with mental disorders, none of them are currently valid as a diagnostic marker (Linden, 2012). Nevertheless, these techniques create a productive basis for brain functional mapping and connectomics studies. These connectome-based approaches present new opportunities in studies of psychiatric diseases, and the identified disrupted networks may potentially represent valuable biomarkers of psychiatric disorders such as depression (Gong and He, 2015).

Another extremely effective recent research tool in biological psychiatry is optogenetics - a method which enables precise control of the activity of neuronal clus- 
ters and has become an effective tool in both neural circuits and behavioral studies (Chen, Zeng, and $\mathrm{Hu}, 2012$; Francis, Chaudhury, and Lobo, 2014; Hegemann and Sigrist, 2013; Yizhar, Fenno, Davidson, Mogri, and Deisseroth, 2011; Zeng and Madisen, 2012). Optogenetic methods have now enabled acquisition of insights into a broad range of questions in behavior, physiology and pathology, spanning domains of sensation, cognition, and action (Deisseroth, 2015). Comprehensively discussed recently (Deisseroth, 2015), these methods continue to contribute to modern biological psychiatry.

Complementary and alternative medicine (CAM) in psychiatry is an integrative approach combining different treatment techniques that concentrate on lifestyle changes, relatively low-invasive natural drugs and traditional medicine practices. These techniques include such treatments as exercise, sleep, nutrition, stress management, light therapy, St. John's Wort (SJW), S-adenosylmethionine (SAMe), yoga, meditation, acupuncture and a variety of spiritual practices (Muskin, 2008; Vora, Aloysi, and Zhuk, 2017). Use of these techniques is especially promising in the treatment of depression, and inclusion of integrative approach treatments based on management and light treatment is highly recommended in both treatment-resistant and recurrent cases (Vora et al., 2017). SJW and SAMe are among the few well studied CAM drugs and may be considered as treatment medication for some patients (Vora et al., 2017).

From a data analysis standpoint, the use of big data grants unparalleled opportunities to investigate different scientific problems. Today, numerous modern technologies, including mobile technologies, social media and internet, can be used to quickly collect and analyze big data from a large number of patients. These practices have already proved to be effective (Swendsen and Salamon, 2012), although they raise various practical and ethical questions, ranging from psychiatrist-patient personal boundaries violation and the ethics of high-scale medical data monitoring (Andlauer, Lydall, Nawka, and Guloksuz, 2015). As these challenges complicate the use of modern technologies by some psychiatrists (Andlauer et al., 2015), digital healthcare data being collected at an incredible speed, at a rate of about $50 \%$ per year (Monteith, Glenn, Geddes, and Bauer, 2015). Thus, there is hope that the growing use of big data in psychiatry will provide opportunities for exploration, descriptive observation, hypothesis generation, and prediction for clinical, research and business issues (Monteith et al., 2015). Indeed, there have already been some promising findings in the following areas: suicide, substance abuse, bipolar disorder, safety of antipsychotic medications, depression management and screening, association of head injuries with psychiatric disorders, the use of natural language processing to identify treatment-resistant depression and the risk of autism (Castro et al., 2015; Grether, An- derson, Croen, Smith, and Windham, 2009; Huybrechts et al., 2012; Kessler et al., 2015; Orlovska et al., 2014; Perlis et al., 2012; Valuck et al., 2012; Wu et al., 2013). Another interesting potential use of big data in psychiatry is finding behavioral traits that were previously difficult or impossible to detect (Monteith et al., 2015).

A good combination of big data with machine learning approaches can also help achieve some goals of personalized medicine, since it should provide high quality treatment prediction for individual cases (Gillan and Whelan, 2017). Personalized medicine, as a concept, was developed a long time ago, first introduced by Hippocrates and not undergone many changes since (Abrahams and Silver, 2010). However, what has changed is the rapid growth of sophisticated methods, theories and an overall understanding of how we should apply these theories to treat individual diseases. Thus, modern personalized medicine is concentrating on finding ways to successfully and most effectively treat each patient based on the knowledge of internal and external factors suggested to be involved in pathogenesis (Emmert-Streib, 2013). Personalized psychiatry looks especially promising since psychiatric patients tend to exhibit significant inter-individual variability in their responses to psychoactive drugs (Costa e Silva, 2013). Unfortunately, the field is still mostly in the information-gathering stage, and a deeper understanding of biomarkers, genes and environmental factors is therefore needed to develop truly personalized psychiatric approaches (Ozomaro, Wahlestedt, and Nemeroff, 2013).

The modern term "holistic psychiatry" is usually described as the "whole self" approach, including mind and body concepts (Wallace, 2008), an increased humanistic aspect in treatment of psychiatric diseases (Linnett, 2006), a systemic (organizational/integrative) view on human behavior (Angyal, 1948) and questioning of our understanding self and identity in a psychiatric context (Crossley, 2012). All of these holistic categories represent the whole-person care approach that is highly desired yet remains hard to reach for biological psychiatry. It is also worth noting that the role of other physiological systems in psychiatric disorders, such as the endocrine, gastrointestinal, immune, and other systems, is beginning to receive increased attention (Ma et al., 2017).

Sex and gender differences are also experiencing resurged interest in current psychiatric practice. Although physicians have been trying to understand the biological differences between men and women for centuries, they continue to face challenges in the context of sexspecific psychiatric diseases. Furthermore, our previous views on such differences were quite sexist and highly based on cultural understanding of gender roles in the past. For instance, maleness has traditionally been seen as superior to femaleness, and some psychiatric diagno- 


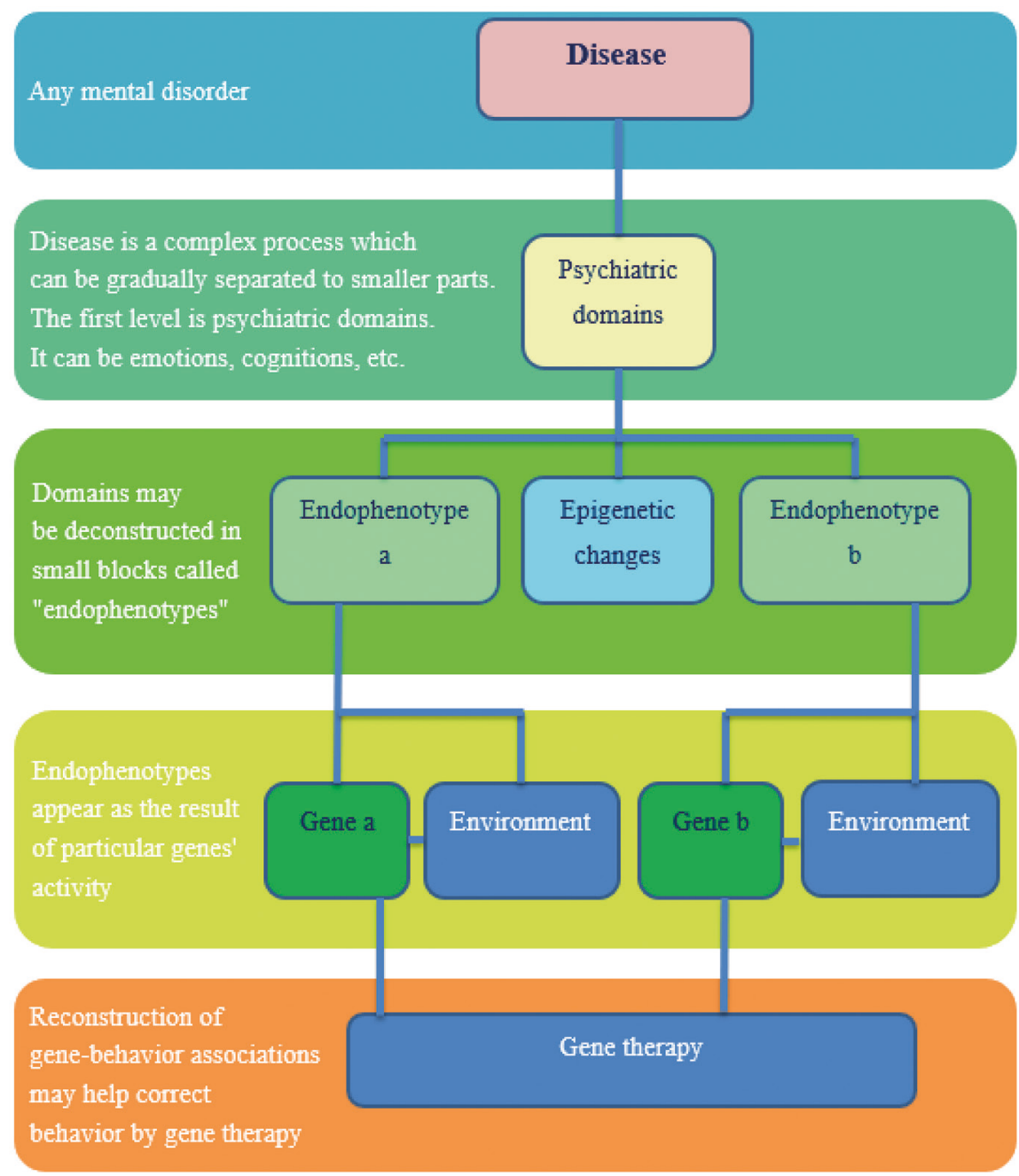

Fig. 4. Endophenotype- and domain-based therapy strategies in biological psychiatry. Human brain diseases may be deconstructed into smaller units - major psychiatric domains (e.g., affect, cognition, activity) - which can be further deconstructed into endophenotypes. As genes' activity modulates behavioral patterns, their interaction leads to a particular endophenotype which results in specific behavioral patterns. Thus, correction of a particular gene's activity may help correct endophenotypes and, eventually, cure the disease that contains this aberrant endophenotype.

ses (e.g., hysteria and borderline personality disorder) were "reserved" for females (Nissim-Sabat, 2013). For today's gender psychiatry, the main challenge is to untangle social and cultural factors from biological (Hirshbein, 2010). Understanding the sex impact on psychiatric disease predisposition and progression may help to increase effectiveness of treatment and make it more personalized.

\section{Discussion}

In conclusion, the need for new methods of treatment necessitates further development of current CNS pathogenesis theories of brain disorders which could explain how exactly psychiatric disorders emerge, how psychological and biological processes develop, and how these disorders relate to treatments. Especially promising here is the approach of translational biopsychiatry, which provides a unique, evolution-based vision of psychiatric diseases. However, there are major problems which biopsychiatry is facing. For example, the field needs novel sensitive biomarkers of psychiatric disorders, especially for its early/presymptomatic progression (Panksepp, 2004b). Another problem, already discussed here, is the need for new classification systems of psychiatric disorders. Many established disease classifications have been justly criticized for a long time for low accuracy, diagnostic heterogeneity, high comorbidity, troubled use and blurred categories (Aragona, 2009b; Baca-Garcia et al., 2007; Kendell and Jablensky, 2003; Pincus, Zarin, and First, 1998). Thus, a new taxonomical system may require a radical rethinking of psychiatric disorders, probably in terms of neurobiological discourse (Aragona, 2009a; Tadafumi Kato, 2011).

Works dedicated to this problem began to appear in the 1970s. For example, Irving Gottesman (1930-2016) 
coined the term "endophenotype" (Fig. 4) and aimed to reconstruct gene-behavior associations by deconstructing complex disorder systems into small blocks (Gottesman and Gould, 2003; Gould and Gottesman, 2006). Endophenotypes are objective, biological or behavioral signs of disorders which exist in an organism regardless of the presence or absence of the disorder, and can be found in a patient's relatives that were not affected by the disease in higher levels than the average population level (Cannon and Keller, 2006; LaPorte et al., 2010). In the last decades, the concept of endophenotype has become widely accepted and is one of the most influential in biological psychiatry (Braff, 2015; Cannon and Keller, 2006; Flint and Munafo, 2014; Glahn et al., 2012; Glahn et al., 2014; Hasler, Drevets, Gould, Gottesman, and Manji, 2006). However, even this concept alone could not solve the problems of the spectrum nature of psychiatric diseases and cross-linking of genetic determinates, molecular pathways, and symptoms (Kalueff, Ren-Patterson, LaPorte, and Murphy, 2008; Kalueff and Stewart, 2015).

One of the recent outcomes of the endophenotype concept was the cross-species trait genetics approach (Kas, Fernandes, Schalkwyk, and Collier, 2007). This approach is based on the idea that behaviors should be conserved in genetic variance across species due to their involvement in common survival mechanisms that allow adaptation to an ever-changing environment. This concept suggests that genotype-phenotype relationships exist between animals and humans in terms of traits (Kas et al., 2007).

Another important concept was developed by the US National Institute of Mental Health (NIMH) as a Research Domain Criteria (RDoC) project (https://www. nimh.nih.gov/research-priorities/rdoc/ (Cuthbert and Insel, 2010; Insel et al., 2010)) to facilitate the translation of modern molecular biology, neuroscience and behavioral approaches in an attempt to better explain the physiology of mental disorders (Ceusters, Jensen, and Diehl, 2017). The concept has created a matrix in which "constructs" (representing aspects of behavior) are related to "elements"/"units of analysis" (representing primarily biomarkers). Constructs are further combined into psychiatric domains; currently 5 psychiatric domains are described: Negative or Positive Valence Systems, Cognitive Systems, Social Processes, Arousal and Regulatory Systems, and an additional $6^{\text {th }}$ Motor Systems Domain is currently under debate (Garvey and Cuthbert, 2017). Currently, this trans-diagnostic approach is actively collecting data for further investigations. Such trans-diagnostic, cross-domain/cross-disorder approaches in psychiatry are receiving increasing attention and are markedly improving our understand of comorbidity, cross-disorder biomarkers and pathologies (Harvey, 2004).

\section{Conclusion}

From the brief historical perspective provided here, one can see that the current problems of biological psychiatry are still the same as they were at its start. Today, like centuries ago, the field still faces the lack of reproducibility; problems with systematization, proper terms and understanding of psychiatric disorders core domains; as well as the lack of humanistic approaches. The field, though rapidly progressing, still lacks connection between psychology and psychiatry, between biology and psychology, between data and valid theories. The lack of disorder progress trajectory-based approaches and the technology alibi still serve as crutches for psychiatric theoretical constructs. To address such problems, a wider use of translational approaches in psychiatry is urgently needed, representing a unique tool to study evolutional conservative traits of disorders pathogenesis. If successful, such an expansion of views on psychiatric disorders may provide a powerful base for new theories and could help create fundamentally new concepts of consciousness and mind across a wide spectrum of organisms.

\section{References}

Abrahams, E., and Silver, M. 2010. The history of personalized medicine; pp. 3-16 in: Gordon, E., and Koslow S. (eds.) Integrative neuroscience and personalized medicine. Oxford, New York: Oxford University Press.

Andlauer, O., Lydall, G., Nawka, A., and Guloksuz, S. 2015. Ethical issues of using information technologies in psychiatry: an early career psychiatrists perspective. European Psychiatry 30:38. https://doi.org/10.1016/S09249338(15)30030-4

Andreasen, N. C. 2004. Brave new brain: Conquering mental illness in the era of the genome. Oxford, New York: Oxford University Press.

Angyal, A. (1948). The holistic approach in psychiatry. American Journal of Psychiatry, 105(3): 178-182. https://doi.org/10.1176/ajp.105.3.178

APA. 1960. Diagnostic and Statistical Manual: Mental Disorders:[DSM I]: American Psychiatric Association.

Aragona, M. 2009a. The concept of mental disorder and the DSM-V.

Aragona, M. 2009b. The role of comorbidity in the crisis of the current psychiatric classification system. Philosophy, Psychiatry, and Psychology 16(1):1-11.

Ayd, F., and Healy, D. (1996). The discovery of antidepressants. The Psychopharmacologists. Interviews by David Healy 1:81-110.

Baca-Garcia, E., Perez-Rodriguez, M. M., Basurte-Villamor, I., Del Moral, A. L. F., Jimenez-Arriero, M. A., De Rivera, J. L. G., . . O Oquendo, M. A. (2007). Diagnostic stability of psychiatric disorders in clinical practice. The British Journal of Psychiatry 190(3):210-216.

Baethge, C., Salvatore, P., and Baldessarini, R. J. (2003). “On cyclic insanity" by Karl Ludwig Kahlbaum, MD: a translation and commentary. Harvard review of psychiatry 11(2):78-90.

Beck, A. T. 1979. Cognitive therapy of depression: Guilford press. 
Berrios, G. E. 1990. Alzheimer's disease: A conceptual history. International Journal of Geriatric Psychiatry 5(6):355-365. https://doi.org/10.1002/gps.930050603

Berrios, G. E. 1996. The history of mental symptoms: descriptive psychopathology since the nineteenth century. Cambridge: Cambridge University Press.

Berrios, G. E., and Hauser, R. 1988. The early development of Kraepelin's ideas on classification: a conceptual history. Psychological medicine 18(4), 813-821.

Berrios, G. E., and Marková, I. S. 2002. Conceptual issues; pp. 1-24 in: D'haenen, H., den Boer, J. A., and Willner, P. Biological psychiatry.

Blair, R. G. 2004. Helping older adolescents search for meaning in depression. Journal of Mental Health Counseling 26(4):333-347.

Boeree, C. G. 2014. Early medicine and physiology. Retrieved from http://webspace.ship.edu/cgboer/neurophysio. html on March, 15.

Bonet, T. 1700. Sepulchretum: sive anatomia practica, ex cadaveribus morbo denatis; proponens historias et observationes omnium pene humani corporis affectuum, ipsorumque causas reconditas revelans; quo nomine tam pathologiae genuinae, quam nosocomiae orthodoxae fundatrix, imo medicinae veteris ac novae promptuarium dici meretur; [4 libris comprehensa and in 2 t. divisa] (Vol. 1): Chouët.

Braff, D. L. 2015. The importance of endophenotypes in schizophrenia research. Schizophrenia Research 163(13):1-8. https://doi.org/10.1016/j.schres.2015.02.007

Burton, R. 1931. The anatomy of melancholy (Vol. 1): G. Routledge.

Cabanis, P.J. G., and Cerise, L. A.P. 1843. Rapports du physique et du moral de l'homme par P.-J.-G. Cabanis: Fortin.

Cade, J. F. 2000. Lithium salts in the treatment of psychotic excitement, 1949. Bulletin of the World Health Organization 78(4):518-520.

Cannon, T. D., and Keller, M. C. 2006. Endophenotypes in the genetic analyses of mental disorders. Annual Review in Clinical Psychology 2:267-290. https://doi.org/10.1146/ annurev.clinpsy.2.022305.095232

Carhart-Harris, R. L., Leech, R., Hellyer, P.J., Shanahan, M., Feilding, A., Tagliazucchi, E., . . . Nutt, D. 2014. The entropic brain: a theory of conscious states informed by neuroimaging research with psychedelic drugs. Frontiers in human neuroscience 8(20). https://doi.org/10.3389/fnhum.2014.00020

Castro, V. M., Minnier, J., Murphy, S. N., Kohane, I., Churchill, S. E., Gainer, V., . . . International Cohort Collection for Bipolar Disorder, C. 2015. Validation of electronic health record phenotyping of bipolar disorder cases and controls. American Journal of Psychiatry 172(4):363-372. https://doi.org/10.1176/appi.ajp.2014.14030423

Ceusters, W., Jensen, M., and Diehl, A. D. 2017. Ontological realism for the research domain Criteria for Mental Disorders. Studies in Health Technology and Informatics 235:431-435

Charney, D. S., Buxbaum, J. D., Sklar, P., and Nestler, E. J. 2013. Neurobiology of mental illness. Oxford, New York: Oxford University Press.

Chen, Q., Zeng, Z., and Hu, Z. 2012. Optogenetics in neuroscience: what we gain from studies in mammals. Neuroscience Bulletin 28(4):423-434. https://doi.org/10.1007/ s12264-012-1250-6

Conry, Y. 1978. Thomas Willis ou le premier discours rationaliste en pathologie mentale. Revue d'histoire des sciences, 31(3):193-231. https://doi.org/10.3406/rhs.1978.1576
Costa e Silva, J.A. 2013. Personalized medicine in psychiatry: new technologies and approaches. Metabolism 62(Suppl 1):S40-44. https://doi.org/10.1016/j.metabol.2012.08.017

Coupland, C., Hill, T., Morriss, R., Arthur, A., Moore, M., and Hippisley-Cox, J. 2015. Antidepressant use and risk of suicide and attempted suicide or self harm in people aged 20 to 64: cohort study using a primary care database. British Medical Journal 350. https://doi.org/10.1136/bmj. h517

Cross-Disorder Group of the Psychiatric Genomics, C. 2013. Identification of risk loci with shared effects on five major psychiatric disorders: a genome-wide analysis. Lancet 381(9875):1371-1379. https://doi.org/10.1016/S01406736(12)62129-1

Cross-Disorder Group of the Psychiatric Genomics, C., Lee, S. H., Ripke, S., Neale, B. M., Faraone, S. V., Purcell, S. M., ... International Inflammatory Bowel Disease Genetics, C. 2013. Genetic relationship between five psychiatric disorders estimated from genome-wide SNPs. Nature Genetics 45(9):984-994. https://doi.org/10.1038/ng.2711

Crossley, D. R. 2012. Holistic psychiatry without the whole self. The Psychiatrist Online 36(3): 97-100.

Cryan, J. F., and Mombereau, C. 2004. In search of a depressed mouse: utility of models for studying depression-related behavior in genetically modified mice. Mol Psychiatry 9(4), 326-357. https://doi.org/10.1038/sj.mp.4001457

Cuijpers, P., van Straten, A., van Oppen, P., and Andersson, G. 2008. Are psychological and pharmacologic interventions equally effective in the treatment of adult depressive disorders? A meta-analysis of comparative studies. Journal of Clinical Psychiatry 69(11): 1675-1685; quiz 1839-1641.

Cuthbert, B. N., and Insel, T. R. 2010. Toward new approaches to psychotic disorders: the NIMH Research Domain Criteria project. Schizophrenia Bulletin 36(6):1061-1062. https://doi.org/10.1093/schbul/sbq108

D'haenen, H. A., den Boer, J. A., and Willner, P. 2002. Biological psychiatry (Vol. 2). Chichester, UK: Wiley.

Davison, K. 2006. Historical aspects of mood disorders. Psychiatry 5(4):115-118.

Deisseroth, K. 2015. Optogenetics: 10 years of microbial opsins in neuroscience. Nature Neuroscience 18(9):12131225. https://doi.org/10.1038/nn.4091

Ellis, A. 1962. Reason and emotion in psychotherapy. Carol Publishing Group.

Emmert-Streib, F. 2013. Personalized medicine: Has it started yet? A reconstruction of the early history. Frontiers in genetics 3: 313. https://doi.org/ 10.3389/fgene.2012.00313

Fears, S. C., Service, S. K., Kremeyer, B., Araya, C., Araya, X., Bejarano, J., ... Bearden, C.E. 2014. Multisystem component phenotypes of bipolar disorder for genetic investigations of extended pedigrees. Journal of American Medical Association, Psychiatry 71(4):375-387. https://doi.org/10.1001/jamapsychiatry.2013.4100

Finger, S. 2000. Chapter 13: Santiago Ramon y Cajal. From nerve nets to neuron doctrine; pp 197-216 in: Minds behind the brain: a history of the pioneers and their discoveries. Oxford: Oxford Scholarships On-line. https:// doi.org/10.1093/acprof:oso/9780195181821.001.0001

Flint, J., and Munafo, M. 2014. Schizophrenia: genesis of a complex disease. Nature 511(7510): 412-413. https://doi.org/10.1038/nature13645

Francis, T.C., Chaudhury, D., Lobo, M. K. 2014. Optogenetics: illuminating the neural basis of rodent behavior. Open Access Animal Physiology 6:33-51. https://doi. org/10.2147/OAAP.S42339 
Frank, R. G. 1980. Harvey and the Oxford physiologists: a study of scientific ideas: University of California Press.

Frankl, V.E.1976. Man's search for ultimate meaning; pp. 182-203 in: Needleman, J. and Lewis D. (eds.), On the Way to Self Knowledge. New York.

Freud, S. 1984. Mourning and melancholia (1911). The standard edition of the complete psychological works of Sigmund Freud, 23.

Gandal, M. J., Haney, J. R., Parikshak, N. N., Leppa, V., Ramaswami, G., Hartl, C., ... Geschwind, D. H. 2018. Shared molecular neuropathology across major psychiatric disorders parallels polygenic overlap. Science 359(6376):693697. https://doi.org/10.1126/science.aad6469

Garvey, M. A., and Cuthbert, B. N. 2017. Developing a Motor Systems Domain for the NIMH RDoC Program. Schizophrenia Bulletin 43(5):935-936. https://doi.org/10.1093/ schbul/sbx095

Gaugler, T., Klei, L., Sanders, S. J., Bodea, C. A., Goldberg, A. P., Lee, A. B., ... Buxbaum, J. D. 2014. Most genetic risk for autism resides with common variation. Nature Genetics 46(8):881-885. https://doi.org/10.1038/ng.3039

Georget, E. J. 1820. De la folie, considérations sur cette maladie: Chez Crevot.

Gert, B. 1996. Hobbes's psychology; pp 157-174 in: The Cambridge Companion to Hobbes.

Gillan, C. M., and Whelan, R. 2017. What big data can do for treatment in psychiatry. Current Opinion in Behavioral Sciences 18:34-42. https://doi.org/10.1016/j.cobeha.2017.07.003

Glahn, D. C., Curran, J.E., Winkler, A. M., Carless, M. A., Kent, J. W., Jr., Charlesworth, J. C., ... Blangero, J. 2012. High dimensional endophenotype ranking in the search for major depression risk genes. Biological Psychiatry 71(1):614. https://doi.org/10.1016/j.biopsych.2011.08.022

Glahn, D. C., Knowles, E. E., McKay, D. R., Sprooten, E., Raventos, H., Blangero, J., ... Almasy, L. 2014. Arguments for the sake of endophenotypes: examining common misconceptions about the use of endophenotypes in psychiatric genetics. American Journal of Medical Genetics, B Neuropsychiatric Genetics 165B(2):122-130. https://doi.org/10.1002/ajmg.b.32221

Gong, Q., and He, Y. 2015. Depression, Neuroimaging and Connectomics: A Selective Overview. Biological psychiatry 77(3):223-235. https://doi.org/10.1016/j.biopsych.2014.08.009

Gottesman, II, and Gould, T.D. 2003. The endophenotype concept in psychiatry: etymology and strategic intentions. American Journal of Psychiatry 160(4):636-645. https://doi.org/10.1176/appi.ajp.160.4.636

Gould, T.D., and Gottesman, II. 2006. Psychiatric endophenotypes and the development of valid animal models. Genes Brain and Behavior 5(2):113-119. https://doi.org/10.1111/j.1601-183X.2005.00186.x

Grether, J. K., Anderson, M. C., Croen, L. A., Smith, D., and Windham, G. C. 2009. Risk of autism and increasing maternal and paternal age in a large north American population. American Journal of Epidemiology 170(9):11181126. https://doi.org/10.1093/aje/kwp247

Griebel, G., and Holmes, A. 2013. 50 years of hurdles and hope in anxiolytic drug discovery. Nature Reviews Drug Discovery 12(9):667-687. https://doi.org/10.1038/nrd4075

Harrington, A. 1999. The placebo effect: An interdisciplinary exploration (Vol. 8): Harvard University Press.

Harvey, A.G.2004. Cognitive behavioural processes across psychological disorders: A transdiagnostic approach to research and treatment: Oxford University Press, USA.
Hasler, G., Drevets, W. C., Gould, T.D., Gottesman, II, and Manji, H. K. 2006. Toward constructing an endophenotype strategy for bipolar disorders. Biological Psychiatry 60(2):93-105. https://doi.org/10.1016/j.biopsych.2005.11.006

Healy, D. 2001. The antidepressant drama.

Hecker, E., and Kraam, A. 2009. 'Hebephrenia. A contribution to clinical psychiatry'by Dr. Ewald Hecker in Gorlitz. 1871. History of psychiatry 20(77 Pt 1):87.

Hegemann, P., and Sigrist, S. 2013. Optogenetics: Walter de Gruyter.

Hippocrates. 2004. Aphorisms: Kessinger Publishing.

Hirshbein, L. 2010. Sex and gender in psychiatry: a view from history. Journal of Medical Humanities 31(2):155-170. https://doi.org/10.1007/s10912-010-9105-5

Hobbes, T.1972. Man and Citizen: De Homine and De Cive: Hackett Publishing.

Hobbes, T., and Macpherson, C. B. 1968. Leviathan; edited with an Introduction by CB Macpherson: Penguin.

Huybrechts, K. F., Schneeweiss, S., Gerhard, T., Olfson, M., Avorn, J., Levin, R., . . . Crystal, S. 2012. Comparative safety of antipsychotic medications in nursing home residents. Journla of American Geriatric Society 60(3):420429. https://doi.org/10.1111/j.1532-5415.2011.03853.x

Huynh, N. N., and McIntyre, R. S. 2008. What Are the Implications of the STAR*D Trial for primary care? A review and synthesis. Primary Care Companion to the Journal of Clinical Psychiatry 10(2):91-96.

Ikeda, M., Okahisa, Y., Aleksic, B., Won, M., Kondo, N., Naruse, N., . . . Iwata, N. 2013. Evidence for shared genetic risk between methamphetamine-induced psychosis and schizophrenia. Neuropsychopharmacology 38(10):18641870. https://doi.org/10.1038/npp.2013.94

Insel, T., Cuthbert, B., Garvey, M., Heinssen, R., Pine, D. S., Quinn, K., ... Wang, P. 2010. Research domain criteria (RDoC): toward a new classification framework for research on mental disorders. American Journal of Psychiatry 167(7):748-751. https://doi.org/10.1176/appi. ajp.2010.09091379

Insel, T. R., and Charney, D.S. 2003. Research on major depression: strategies and priorities. Journal of American Medical Association 289(23):3167-3168. https://doi. org/10.1001/jama.289.23.3167

Ivleva, E. I., Morris, D. W., Moates, A. F., Suppes, T., Thaker, G. K., and Tamminga, C.A. 2010. Genetics and intermediate phenotypes of the schizophrenia-bipolar disorder boundary. Neuroscience Biobehavioral Review 34(6):897921. https://doi.org/10.1016/j.neubiorev.2009.11.022

Johnstone, E. C., Crow, T. J., Frith, C. D., Husband, J., and Kreel, L. 1976. Cerebral ventricular size and cognitive impairment in chronic schizophrenia. Lancet 2(7992):924-926.

Kagan, J., Snidman, N., Arcus, D., and Reznick, J. S. 1994. Galen's prophecy: Temperament in human nature: Basic Books.

Kahlbaum, K. 1973. Catatonia (1874). Translated by Levij Y, Pridan T. Baltimore, MD: Johns Hopkins University Press.

Kahlbaum, K. L. 1863. Die Gruppierung der psychischen Krankheiten und die Eintheilung der Seelenstörungen: Entwurf einer historisch-kritischen Darstellung der bisherigen Eintheilungen und Versuch zur Anbahnung einer empirisch-wissenschaftlichen Grundlage der Psychiatrie als klinischer Disciplin: Kafemann.

Kahlbaum, K. L., and Berrios, G. 1996. Die Gruppirung der psychischen Krankheiten... Part III: (The classification of mental disorders... Part III). History of psychiatry 7(25):167-170. 
Kalueff, A. V., Ren-Patterson, R. F., LaPorte, J.L., and Murphy, D. L. 2008. Domain interplay concept in animal models of neuropsychiatric disorders: a new strategy for high-throughput neurophenotyping research. Behavioral Brain Research 188(2):243-249. https://doi.org/10.1016/j.bbr.2007.11.011

Kalueff, A.V., and Stewart, A.M. 2015. Modeling neuropsychiatric spectra to empower translational biological psychiatry. Behavioral Brain Research 276:1-7. https://doi.org/10.1016/j.bbr.2014.01.038

Kas, M.J., Fernandes, C., Schalkwyk, L.C., and Collier, D. A. 2007. Genetics of behavioural domains across the neuropsychiatric spectrum; of mice and men. Molecular Psychiatry 12(4):324-330. https://doi.org/10.1038/ sj.mp.4001979

Kato, T. 2009. Epigenomics in psychiatry. Neuropsychobiology 60(1):2-4. https://doi.org/10.1159/000234810

Kato, T. 2011. A renovation of psychiatry is needed. World Psychiatry 10(3):198-199.

Kendell, R., and Jablensky, A. 2003. Distinguishing between the validity and utility of psychiatric diagnoses. American Journal of Psychiatry 160(1):4-12.

Kendler, K.S., and Engstrom, E.J. 2016. Kahlbaum, Hecker, and Kraepelin and the transition from psychiatric symptom complexes to empirical disease forms. American Journal of Psychiatry 174(2):102-109.

Kessler, R. C., Warner, C. H., Ivany, C., Petukhova, M. V., Rose, S., Bromet, E. J., . . . Army, S. C. 2015. Predicting suicides after psychiatric hospitalization in US Army soldiers: the Army Study To Assess Risk and rEsilience in Servicemembers (Army STARRS). Journal of American Medical Association, Psychiatry 72(1):49-57. https://doi.org/10.1001/jamapsychiatry.2014.1754

Kraam, A. 2004. On the Origin of the Clinical Standpoint in Psychiatry: By Dr Ewald Hecker in Görlitz. History of psychiatry 15(3):345-360.

Kraepelin, E. 1905. Fragestellungen der klinischen Psychiatrie. Cbl. fur Nervenheilk und Psychiatric 8: 573.

Kraepelin, E. 1983. Lebenserinnerungen. Herausgegeben von H. Hippius, G. Pieters, D. Ploog: Berlin: Springer.

Kuhn, R. 1958. The treatment of depressive states with $G$ 22355 (imipramine hydrochloride). American Journal of Psychiatry 115(5):459-464.

Lanczik, M. 1988. Der Breslauer Psychiater Carl Wernicke. Werkanalyse und Wirkungsgeschichte als Beitrag zur Medizingeschichte Schlesiens (Sigmaringen: Thorbecke).

Lapin, I., and Oxenkrug, G. 1969. Intensification of the central serotoninergic processes as a possible determinant of the thymoleptic effect. The Lancet 293(7586):132-136.

LaPorte, J. L., Egan, R. J., Hart, P. C., Bergner, C. L., Cachat, J. M., Canavello, P. R., and Kalueff, A. V. 2010. Qui non proficit, deficit: experimental models for 'integrative' research of affective disorders. Journal of Affective Disorders 121(12):1-9. https://doi.org/10.1016/j.jad.2009.04.010

Lee, R., and Avramopoulos, D. 2014. Chapter 1 - Introduction to Epigenetics in Psychiatry; pp. 3-25 in: Epigenetics in Psychiatry. Boston: Academic Press.

Lewis, A.J. 1934. Melancholia: a clinical study of depressive states. Journal of Mental Science 80:277-378. http://dx.doi.org/10.1192/bjp.80.329.277

Lindemann, M. 2010. Medicine and society in early modern Europe: Cambridge University Press.

Linden, D.E. 2012. The challenges and promise of neuroimaging in psychiatry. Neuron 73(1):8-22. https://doi.org/10.1016/j.neuron.2011.12.014
Linden, D. E., and Fallgatter, A. J. 2009. Neuroimaging in psychiatry: from bench to bedside. Frontiers in Human Neuroscience 3:49. https://doi.org/10.3389/neuro.09.049.2009

Linnett, P. 2006. Making connections: towards a holistic psychiatry. Spirituality and Health International 7(1):40-47.

Lloyd, G. 1983. Introduction to Hippocratic Writings. Translated by J. Chadwick and WN Mann: Harmondsworth, UK: Penguin.

López-Muñoz, F., Alamo, C., Cuenca, E., Shen, W. W., Clervoy, P., and Rubio, G. 2005. History of the discovery and clinical introduction of chlorpromazine. Annals of Clinical Psychiatry 17(3):113-135.

López-Munoz, F., Alamo, C., Juckel, G., and Assion, H.-J. 2007. Half a century of antidepressant drugs: on the clinical introduction of monoamine oxidase inhibitors, tricyclics, and tetracyclics. Part I: monoamine oxidase inhibitors. Journal of Clinical Psychopharmacology 27(6):555-559.

Lutz, P. L. 2002. The rise of experimental biology: an illustrated history: Springer Science and Business Media.

Ma, L., Demin, K. A., Kolesnikova, T. O., Kharsko, S. L., Zhu, X., Yuan, X., ... Kalueff, A. V. 2017. Animal inflammationbased models of depression and their application to drug discovery. Expert Opinion on Drug Discovery 12(10):9951009. https://doi.org/10.1080/17460441.2017.1362385

Mayberg, H. S., Silva, J. A., Brannan, S. K., Tekell, J. L., Mahurin, R. K., McGinnis, S., and Jerabek, P. A. 2002. The functional neuroanatomy of the placebo effect. American Journal of Psychiatry 159(5):728-737.

McHugh, P., and Slavney, P. 1998. The Perspectives of Psychiatry. Baltimore and London: Johns Hopkins University Press.

McMahon, F.J., and Insel, T.R. 2012. Pharmacogenomics and personalized medicine in neuropsychiatry. Neuron 74(5):773-776. https://doi.org/10.1016/j.neuron.2012.05.004

Meyer-Lindenberg, A., and Weinberger, D. R. 2006. Intermediate phenotypes and genetic mechanisms of psychiatric disorders. Nature Reviews Neuroscience 7(10):818-827. https://doi.org/10.1038/nrn1993

Meynert, T. 1885. Psychiatry: Clinical treatise on the diseases of the fore-brain. New York and London: GP Putnam.

Misgeld, T., and Kerschensteiner, M. 2006. In vivo imaging of the diseased nervous system. Nature Review Neuroscience 7(6):449-463. https://doi.org/10.1038/nrn1905

Moerman, D. E. 2002. Meaning, Medicine, and the" placebo Effect" (Vol. 28). Cambridge: Cambridge University Press.

Monteith, S., Glenn, T., Geddes, J., and Bauer, M. 2015. Big data are coming to psychiatry: a general introduction. International Journal of Bipolar Disorder 3(1):21. https://doi.org/10.1186/s40345-015-0038-9

Morgagni, G. 1769. The seats and causes of diseases investigated by anatomy; in five books, containing a great variety of dissections, with remarks. To which are added very accurate and copious indexes of the principal things and names therein contained. Vol. 2. London, Printed for A. Millar, and T. Cadell, his successor [etc.].

Murad, I., and Gordon, H. 2002. Psychiatry and the Palestinian population. The Psychiatrist 26(1):28-30.

Murphy, D. L., Uhl, G. R., Holmes, A., Ren-Patterson, R., Hall, F. S., Sora, I., . . . Lesch, K. P. 2003. Experimental gene interaction studies with SERT mutant mice as models for human polygenic and epistatic traits and disorders. Genes Brain and Behavior 2(6):350-364.

Murray, C.J., and Lopez, A.D. 1997. Alternative projections of mortality and disability by cause 1990-2020: Global 
burden of disease study. Lancet 349(9064): 1498-1504. https://doi.org/10.1016/S0140-6736(96)07492-2

Muskin, P. R. 2008. Complementary and alternative medicine and psychiatry. American Psychiatric Pub.

Nestler, E. J., and Hyman, S. E. 2010. Animal models of neuropsychiatric disorders. Nature Neuroscience 13(10):11611169. https://doi.org/10.1038/nn.2647

Nissim-Sabat, M. 2013. Race and gender in philosophy of psychiatry: Science, relativism, and phenomenology; pp. 139-158 in: Fulford, K. W. M., Davies, M., Gipps, R. G. T., Graham, G., Sadler, J. Z., Stanghellini, G., and Thornton, T. (eds.) The Oxford Handbook of Philosophy and Psychiatry.

Orlovska, S., Pedersen, M. S., Benros, M. E., Mortensen, P. B., Agerbo, E., and Nordentoft, M. 2014. Head injury as risk factor for psychiatric disorders: a nationwide registerbased follow-up study of 113,906 persons with head injury. American Journal of Psychiatry 171(4):463-469. https://doi.org/10.1176/appi.ajp.2013.13020190

Ozomaro, U., Wahlestedt, C., and Nemeroff, C. B. (2013. Personalized medicine in psychiatry: problems and promises. BMC Medicine 11:132. https://doi.org/10.1186/17417015-11-132

Panksepp, J. 2004a. Affective neuroscience: The foundations of human and animal emotions. Oxford University Press.

Panksepp, J. 2004b. Biological psychiatry sketched - past, present, and future; pp. 3-32 in: Textbook of biological psychiatry.

Panksepp, J.2004c. Textbook of biological psychiatry. John Wiley and Sons.

Peedicayil, J., Grayson, D. R., and Avramopoulos, D. 2014. Epigenetics in psychiatry. Elsevier.

Perlis, R. H., Iosifescu, D. V., Castro, V. M., Murphy, S. N., Gainer, V. S., Minnier, J., ... Smoller, J. W. 2012. Using electronic medical records to enable large-scale studies in psychiatry: treatment resistant depression as a model. Psychological Medicine 42(1):41-50. https://doi.org/10.1017/ S0033291711000997

Petrovic, P., Kalso, E., Petersson, K. M., and Ingvar, M. 2002. Placebo and opioid analgesia-imaging a shared neuronal network. Science 295(5560):1737-1740.

Pincus, H.A., Zarin, D.A., and First, M. 1998. Clinical significance and DSM-IV. Archives of general psychiatry 55(12):1145-1145.

Porter, R. 1988. Dizionario biografico della storia della medicina e delle scienze naturali (liber amicorum).

Preston, J., O'Neal, J. H., and Talaga, M. C. 2010. Handbook of clinical psychopharmacology for therapists. New Harbinger Publications.

Radden, J. 2003. Is This Dame Melancholy?: Equating today's depression and past melancholia. Philosophy, Psychiatry, and Psychology 10(1):37-52.

Roach, I. H., Bronner, F., and Oreffo, R. 2011. Epigenetic Aspects of Chronic Diseases. Springer.

Robitzek, E. H., Selikoff, I. J., Mamlok, E., and Tendlau, A. 1953. Isoniazid and its isopropyl derivative in the therapy of tuberculosis in humans: comparative therapeutic and toxicologic properties. Diseases of the Chest 23(1):1-15.

Schildkraut, J. J. 1965. The catecholamine hypothesis of affective disorders: a review of supporting evidence. American Journal of Psychiatry 122(5):509-522.

Schizophrenia Working Group of the Psychiatric Genomics, C. 2014. Biological insights from 108 schizophrenia-associated genetic loci. Nature 511(7510):421-427. https://doi.org/10.1038/nature13595

Schmidt, M. V., Wang, X. D., and Meijer, O. C. 2011. Early life stress paradigms in rodents: potential animal models of depression? Psychopharmacology (Berl) 214(1):131-140. https://doi.org/10.1007/s00213-010-2096-0

Scholl, R. 2002. Der Papyrus Ebers: die grösste Buchrolle zur Heilkunde Altägyptens (Vol. 7): (Schriften aus der Universitätsbibliothek Leipzig) Taschenbuch - 1 .

Seidner, S. S. 2009. A Trojan Horse: Logotherapeutic transcendence and its secular implications for theology. Mater Dei Institute 10-12.

Selikoff, I. J., and Robitzek, E. H. (1952). Tuberculosis chemotherapy with hydrazine derivatives of isonicotinic acid. Diseases of the Chest 21(4):385-438.

Shapiro, A. K., and Shapiro, E. 2000. The powerful placebo: From ancient priest to modern physician. JHU Press.

Solms, M., and Turnbull, O.2002. The brain and the inner world: An introduction to the neuroscience of subjective experience. Karnac Books.

Spiegel, R. 2003. Psychopharmacology: an introduction. John Wiley and Sons.

Stein, D. J., and Ludik, J. 1998. Neural networks and psychopathology: Connectionist models in practice and research. Cambridge: Cambridge University Press.

Stone, M. H. 1997. Healing the mind: A history of psychiatry from antiquity to the present. WW Norton and Company.

Sudhoff, K., and Garrison, F. H. 1926. Essays in the History of Medicine. New York: Medical Life Press

Swendsen, J., and Salamon, R. 2012. Mobile technologies in psychiatry: providing new perspectives from biology to culture. World Psychiatry 11(3):196-198.

Tsankova, N., Renthal, W., Kumar, A., and Nestler, E. J. 2007. Epigenetic regulation in psychiatric disorders. Nature Reviews Neuroscince 8(5):355-367. https://doi.org/10.1038/ nrn2132

Uddin, M., Tammimies, K., Pellecchia, G., Alipanahi, B., Hu, P., Wang, Z., ... Scherer, S. W. 2014. Brain-expressed exons under purifying selection are enriched for de novo mutations in autism spectrum disorder. Nature Genetics 46(7):742-747. https://doi.org/10.1038/ng.2980

Valenstein, E. S. 1974. Brain control: A critical examination of brain stimulation and psychosurgery. John Wiley and Sons.

Valuck, R. J., Anderson, H. O., Libby, A. M., Brandt, E., Bryan, C., Allen, R. R., ... Pace, W. D. 2012. Enhancing electronic health record measurement of depression severity and suicide ideation: a Distributed Ambulatory Research in Therapeutics Network (DARTNet) study. The Journal of the American Board of Family Medicine 25(5):582-593. https://doi.org/10.3122/jabfm.2012.05.110053

Van Sertima, I. 1992. Golden age of the Moor. (series Journal of African Civilizations 11). New Brunswick, U. S. A. : Transaction Publishers

von Monakow, C., and Mourgue, R. 1928. Introduction biologique à l'étude de la neurologie et de la psychopathologie: intégration et désintégration de la fonction. F. Alcan.

Vora, E., Aloysi, A., and Zhuk, R. 2017. Complementary and Alternative Medicine; pp 383-387 in Psychiatry. Mount Sinai Expert Guides.

Wallace, E. R. 2008. Two "mind"-"body" models for a holistic psychiatry; pp. 695-723 in History of psychiatry and medical psychology. Springer.

Wassmann, C. 2010. Reflections on the "body loop": Carl Georg Lange's theory of emotion. Cognition and Emotion 24(6):974-990.

Wernicke, C.1906. Grundriss der Psychiatrie in klinischen Vorlesungen. Thieme.

Wickens, A.P. 2014. A history of the brain: from stone age surgery to modern neuroscience. Hove, UK: Psychology Press. 
Willis, T., and Guidott, T. 1992. The London practice of physick. Classics of Medicine Library.

Wong, M. L., and Licinio, J. 2004. From monoamines to genomic targets: a paradigm shift for drug discovery in depression. Nature Reviews Drug Discovery 3(2):136-151. https://doi.org/10.1038/nrd1303

Wray, N. R., Lee, S. H., Mehta, D., Vinkhuyzen, A. A., Dudbridge, F., and Middeldorp, C. M. 2014. Research review: Polygenic methods and their application to psychiatric traits. J Child Psychology and Psychiatry 55(10): 1068-1087. https://doi.org/10.1111/jcpp.12295

Wu, L. T., Gersing, K. R., Swartz, M. S., Burchett, B., Li, T. K., and Blazer, D. G. 2013. Using electronic health records data to assess comorbidities of substance use and psychiatric diagnoses and treatment settings among adults. Journal of Psychiatric Research 47(4): 555-563. https://doi.org/10.1016/j.jpsychires.2012.12.009

Yasui, D., Peedicayil, J., and Grayson, D. R. 2016. Neuropsychiatric Disorders and Epigenetics. Academic Press.

Yizhar, O., Fenno, L. E., Davidson, T.J., Mogri, M., and Deisseroth, K. 2011. Optogenetics in neural systems. Neuron 71(1):9-34. https://doi.org/10.1016/j.neuron.2011.06.004

Zeng, H., and Madisen, L. 2012. Mouse transgenic approaches in optogenetics. Progress in Brain Research 196:193-213. https://doi.org/10.1016/B978-0-444-59426-6.00010-0 